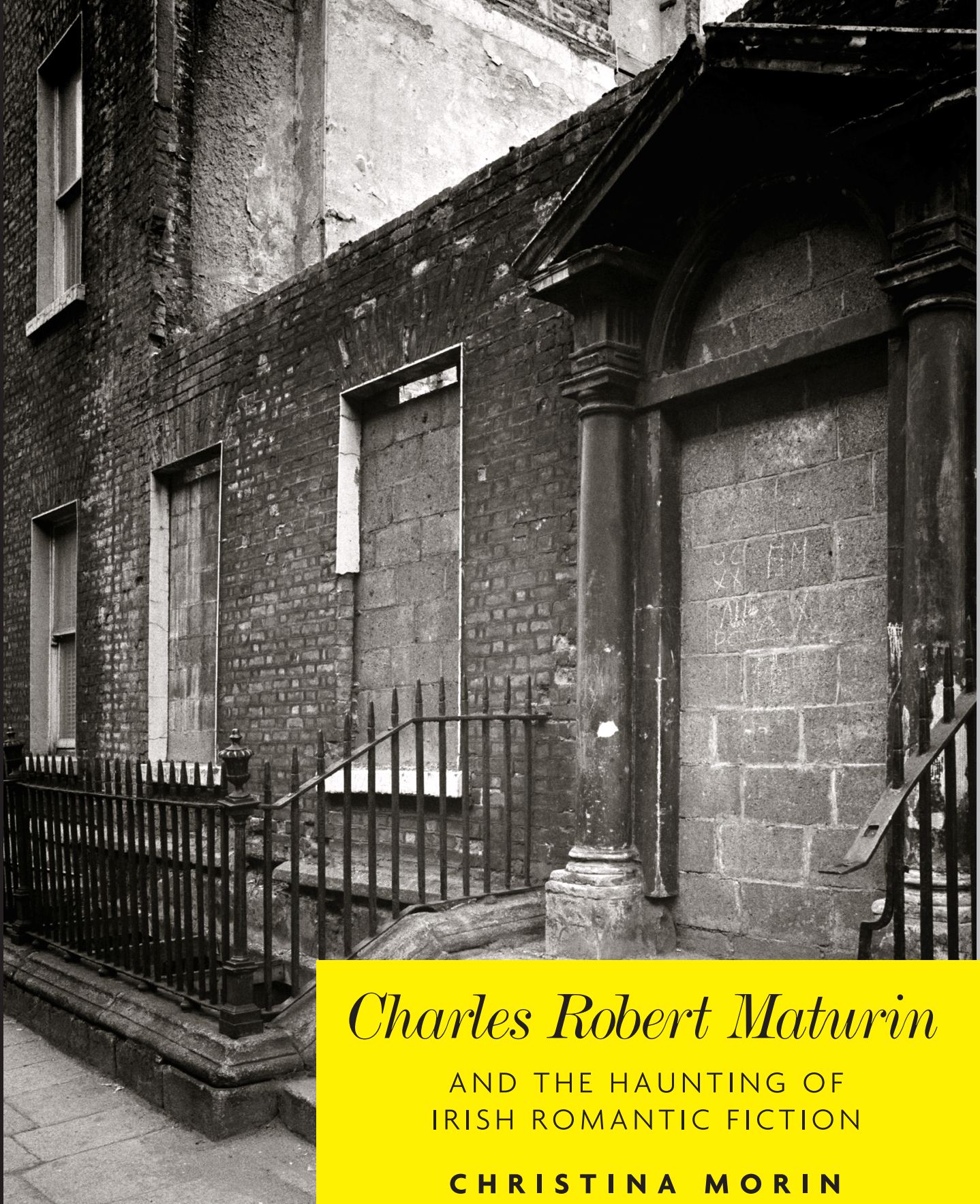




\section{Charles Robert Maturin and the haunting of Irish Romantic fiction}

\section{MANCHESTER 1824}

Manchester University Press 


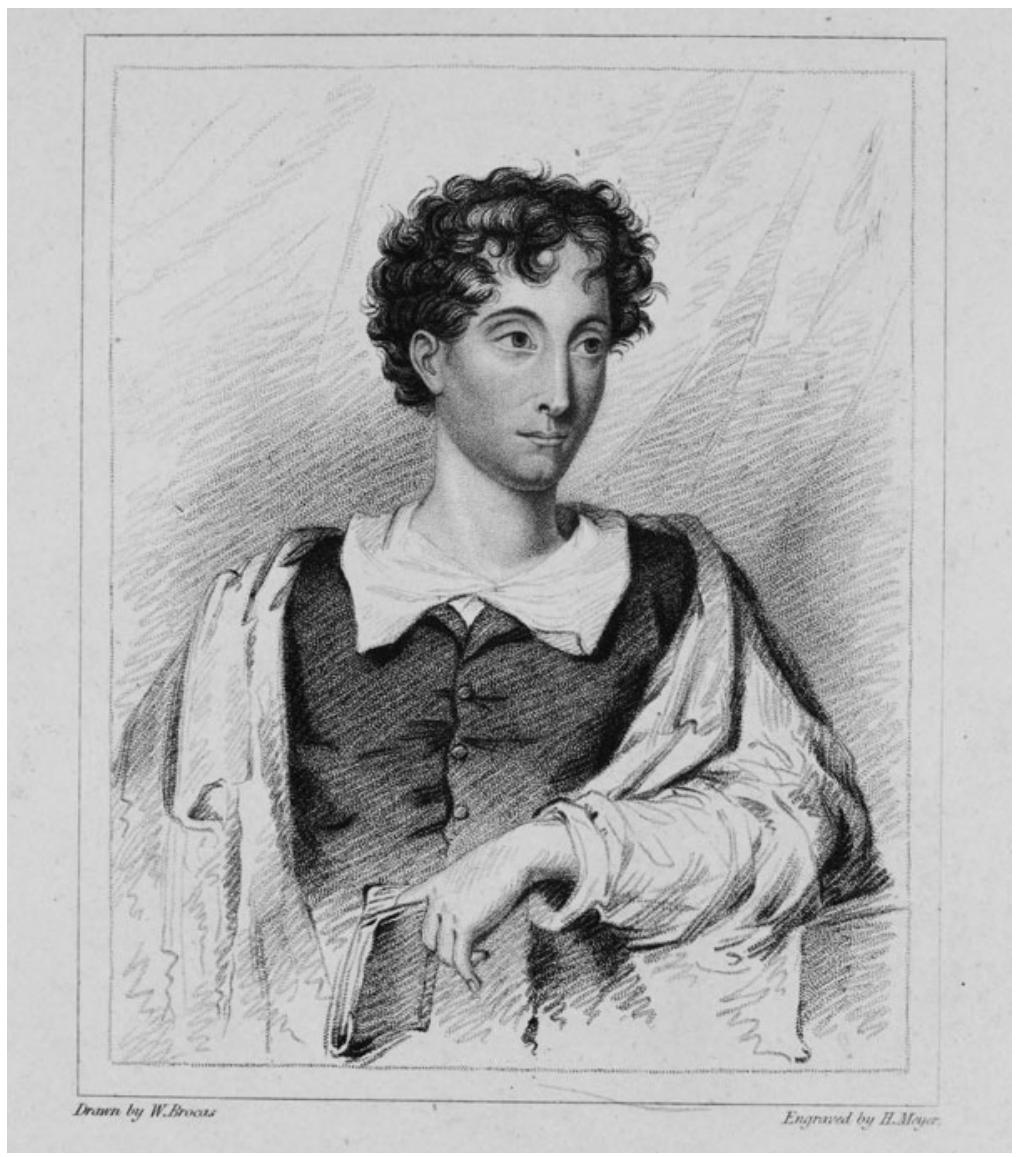

Half-length portrait of Maturin painted by William Brocas (c. 1794-1868), later engraved by Henry Hoppner Meyer (1782-1847), and published in the New monthly magazine in 1819 . 


\section{Charles Robert}

Maturin and the

haunting of Irish

Romantic fiction

Christina Morin

Manchester University Press

Manchester 


\section{Copyright (C) Christina Morin 2011}

The right of Christina Morin to be identified as the author of this work has been asserted by her in accordance with the Copyright, Designs and Patents Act 1988.

Published by Manchester University Press

Altrincham Street, Manchester M1 7JA

www.manchesteruniversitypress.co.uk

British Library Cataloguing-in-Publication Data

A catalogue record for this book is available from the British Library

Library of Congress Cataloging-in-Publication Data applied for

ISBN 9780719085321 hardback

First published 2011

The publisher has no responsibility for the persistence or accuracy of URLs for any external or third-party internet websites referred to in this book, and does not guarantee that any content on such websites is, or will remain, accurate or appropriate.

Typeset in $10 / 12$ pt Perpetua

by Servis Filmsetting Ltd, Stockport, Cheshire 